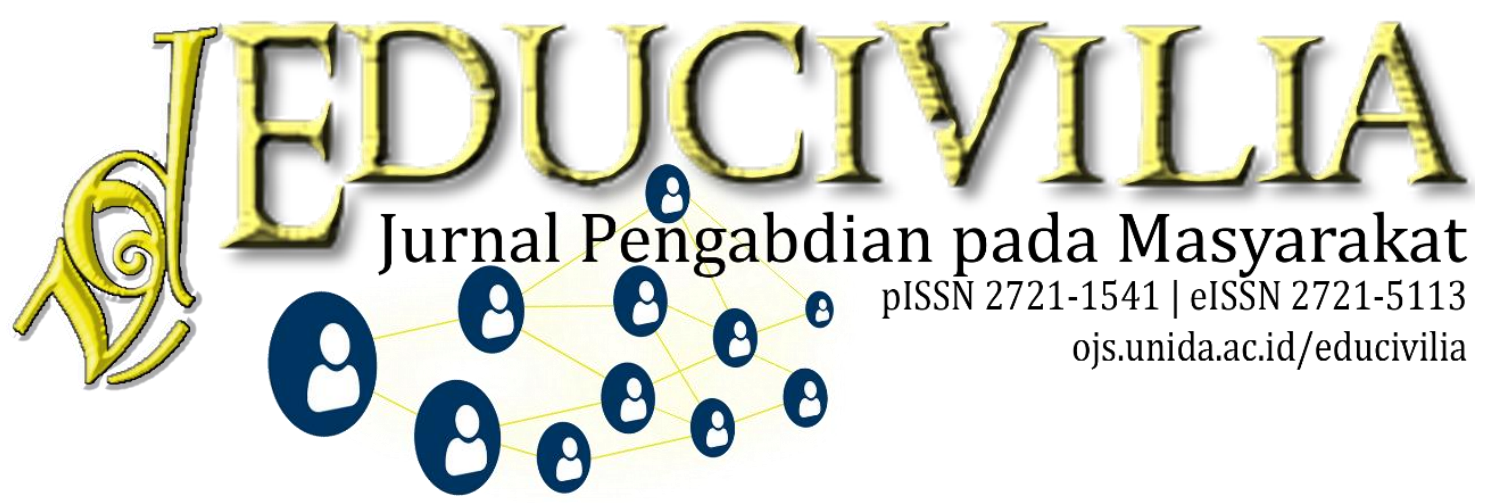

\title{
Rumah Pintar : Bimbingan Belajar Siswa Sekolah Dasar di Masa Pandemi Covid-19
}

\author{
Resti Yektyastuti ${ }^{1}$, Lulu Nuroniah², Fitriamah³, Linda Julia4, Meli Andiani ${ }^{5}$ \\ 1,2,3,4,5 Program Studi Pendidikan Guru Sekolah Dasar Fakultas Keguruan dan Ilmu Pendidikan \\ Universitas Djuanda Bogor; Jl. Tol Ciawi No. 1 Kotak Pos 35, Ciawi Bogor 16720
}

Kilas Artikel

Volume 2 Nomor 1

Januari 2021: 83-91

DOI: $10.30997 /$ ejpm.v2i1.3585

Article History

Submission: 20-11-2020

Revised: 25-12-2020

Accepted: 19-01-2021

Published: 30-01-2021

Kata Kunci:

Pandemi Covid-19, Bimbingan

Belajar,

Rumah Pintar.

Keywords:

Covid-19 Pandemic, Tutoring,

Rumah Pintar.

Korespondensi:

Resti Yektyastuti

restiy@unida.ac.id

\begin{abstract}
Abstrak
Program Rumah Pintar merupakan program bimbingan belajar bagi siswa sekolah dasar di masa pandemic Covid-19 selama 2020. Rumah Pintar dirancang sebagai pusat sumber pembelajaran setelah kegiatan pembelajaran oleh pihak sekolah. Program ini bertujuan untuk meningkatkan mutu pendidikan peserta didik dan membantu peserta didik pada Pendidikan Jarak Jauh (PJJ) di Masa Pandemi Covid-19. Kegiatan dilaksanakan di Kampung Maleber dan Kampung Sudimampir, Desa Sukahami, Kecamatan Megamendung, Kabupaten Bogor, Jawa Barat. Bentuk kegiatan yang dilaksanakan terdiri dari bimbingan mata pelajaran matematika dan bimbingan membaca, menulis, dan berhitung (CALISTUNG). Kegiatan ini memberikan hasil berupa peningkatan pemahaman dan pengetahuan peserta didik akan pentingnya belajar meskipun fasilitas pembelajaran jarak jauh kurang mencukupi, membuhkan semangat belajar peserta didik untuk menimba ilmu dan menguasai kemampuan matematika dan CALISTUNG, tentunya dengan mematuhi protokol kesehatan.

The Rumah Pintar: Tutoring Program for Elementary School Students during Covid-19 Pandemic

Abstract

The Rumah Pintar Program is a tutoring program for elementary school students during the Covid-19 pandemic in 2020. Rumah Pintar is designed as a learning resource center after learning activities by the school. This activity aims to improve the quality of education of students and help students in Distance Learning during the Covid-19 Pandemic. The program was carried out in Kampung Maleber and Kampung Sudimampir, Sukamahi Village, Megamendung District, Bogor Regency, West Java. The form of activities carried out consists of tutoring mathematics subjects and tutoring in reading, writing and arithmetic. This program results increasing of students' understanding and knowledge of the importance of learning even though distance learning facilities are insufficient, encouraging students to learn and master mathematical skills and also in reading, writing, and arithmetic, of course by complying health protocols.
\end{abstract}


PENDAHULUAN

Pengabdian masyarakat sebagai suatu kegiatan yang bertujuan membantu masyarakat tertentu dalam beberapa aktivitas tanpa mengharapkan imbalan dalam bentuk apapun. Pengabdian kepada Masyarakat adalah pengamalan dari ilmu pengetahuan, teknologi, dan seni yang dilakukan oleh perguruan tinggi secara melembaga dan langsung kepada masyarakat untuk turut mensukseskan terciptanya masyarakat yang sejahtera serta meningkatkan misi dan fungsi lembaga perguruan tinggi. (Pelaksanaan, 2014)

Secara umum program ini dirancang oleh berbagai universitas atau institut yang ada di Indonesia untuk memberikan kontribusi nyata bagi bangsa Indonesia, khususnya dalam mengembangkan kesejahteraan dan kemajuan bangsa Indonesia.

Ki Hajar Dewantara mengartikan pendidikan sebagai daya upaya untuk memajukan budi pekerti, pikiran serta jasmani anak, agar dapat memajukan kesempurnaan hidup yaitu hidup dan menghidupkan anak yang selaras dengan alam dan masyarakatnya (Nurkholis, 2013). Aspek pendidikan menjadi salah satu aspek yang banyak pengalami dampak dalam masa pandemic Covid-19 sepanjang tahun 2020.

Covid-19 adalah penyakit menular yang disebabkan oleh jenis coronavirus yang baru ditemukan. Walaupun lebih banyak menyerang ke lansia, virus ini sebenarnya bisa juga menyerang siapa saja, mulai dari bayi, anak-anak, hingga orang dewasa. Virus corona ini bisa menyebabkan ganguan ringan pada sistem pernapasan, infeksi paru-paru yang berat, hingga kematian.

Sebagai upaya untuk mencegah pandemi Covid-19, pemerintah mengeluarkan kebijakan agar sekolahsekolah meminta siswanya untuk belajar di rumah. Mulai 16 Maret 2020 sekolah menerapkan metode pembelajaran siswa secara daring. (SKB 4 Menteri, 2020; Kemenkes, 2020)

Sejak 1 Juli 2020, pemerintah menetapkan sebuah sistem baru yang diterapkan pasca PSBB, yaitu Adaptasi Kebiasaan Baru. Tatanan kebiasaan baru menjadi upaya menjembatani pembangunan kesehatan dan ekonomi akibat pandemi COVID-19 yang belum jelas kapan selesainya. Adaptasi tatanan kebiasaan baru ditengah pandemi COVID-19 dilakukan oleh berbagai 
tingkatan pemerintahan dan beberapa pihak secara kolaboratif, tak terkecuali peran perguruan tinggi dalam dharma pengabdian kepada masyarakat. (Satria \& Hasanah, 2019)

Sistem pendidikan jarak jauh (PJJ), yang dipersepsikan sebagai inovasi abad 21, merupakan sistem pendidikan yang memiliki daya jangkau luas lintas ruang, waktu, dan sosioekonomi. Sistem PJJ membuka akses terhadap pendidikan bagi siapa saja, di mana saja, dan kapan saja. Dengan karakteristik tersebut, sistem PJJ seringkali dianggap sebagai solusi terhadap berbagai masalah pendidikan, terutama yang berkaitan dengan pemerataan dan demokratisasi pendidikan, serta perluasan akses terhadap pendidikan berkualitas kepada seluruh lapisan masyarakat lintas ruang dan waktu.

Melalui berbagai perangkat hukum yang telah dikeluarkan pemerintah, yaitu SK Mendiknas No. 107/U/2001, UU Sisdiknas No. 20/2003, PP 17/2010, dan juga PP 66/2010, sistem PJJ sudah menjadi bagian yang menyatu dalam dunia pendidikan di Indonesia, dan menjadi pilihan bagi masyarakat untuk memperoleh akses terhadap pendidikan, termasuk pendidikan guru dan tenaga kependidikan. Situasi ini mendorong berbagai institusi pendidikan, terutama pendidikan tinggi, untuk berpartisipasi aktif dalam pendidikan jarak jauh. Terlepas dari diterapkannya Pendidikan Jarak Jauh (PJJ) yang dicanangkan, terdapat kendala nyata pada pelaksanaan di lapangan dimana tidak semua peserta didik memiliki fasilitas untuk menunjang pembelajaran daring. (Pengantar, 2011)

Salah satu kegiatan yang membantu peserta didik mengembangkan diri dalam meningkatkan kemampuan dalam pembelajaran ialah bimbingan belajar. Meskipun bimbingan belajar memberikan pengaruh pada kejenuhan belajar siswa (Nihayah, 2018), namun bimbingan belajar dapat meningkatkan motivasi belajar siswa (Huda, J: 2013) dan nilai akademik (Armiatin, 2015; Meidyna, F.G., 2018; Nurhayati, 2016). Bimbingan belajar adalah "bimbingan dalam hal menemukan cara belajar yang tepat, dalam memilih program setudi yang sesuai, dan dalam mengatasi kesukaran-kesukaran yang timbul berkaitan dengan tuntunan-tuntunan belajar di suatu institusi pendidikan". (El Fiah \& Purbaya, 2016) Berdasarkan uraian di atas, bimbingan belajar 
sebagai sarana untuk membantu peserta didik dalam mata pelajaran.

Rumah Pintar sudah banyak tumbuh di Indonesia (Marsuki, 2017; Ardiyanti, 2019, sehingga pola yang serupa juga ditarapkan di Desa Sukamahi Kecamatan Megamendung Kabupaten Bogor Jawa Barat ini. Dengan dibuatnya program Rumah Pintar ini diharapkan peserta didik dapat mempersiapkan dan menghadapi perkembangan zaman dan perubahan sosial.

\section{METODE}

Pelakaanaan kegiatan pengabdian masyarakat ini berlangsung selama bulan Juli hingga Agustus 2020. Kegiatan ini bertempat di Madrasah Kampung Sudimampir dan TKQ PLUS AN-NUR Kampung Maleber, Desa Sukamahi Kabupaten Bogor Jawa Barat.

Pengabdian ini dilaksanakan dengan membuat beberapa program pendidikan, salah satunya Rumah Pintar. Rumah Pintar yang penyusun lakukan yaitu memanfaatkan fasilitas umum kampung untuk ruang belajar, dengan meja yang dibuat formasi berbentuk huruf $U$ dan lain sebagainya.
Terdapat beberapa hal yang dijadikan acuan program Rumah Pintar guna mensuksekkan program ini.

a. Terdapat Madrasah dan Sekolah TKQ PLUS AN-NUR yang dapat dijadikan sebagai tempat Rumah Pintar.

b. Terdapat anak-anak sekolah yang tidak memiliki fasilitas untuk menunjang Pendidikan Jarak Jauh (PJJ).

c. Program Rumah Pintar hadir dengan dukungan dari pihak Sekolah, Orang tua, dan peserta didik dengan intensitas waktu mengajar disesuaikan dengan kebutuhan.

Sebagai sumber belajar Utama, program Rumah Pintar melaksanakan kegiatan yang terdiri dari :

1) Bimbingan Belajar yang dilaksanakan menggunakan metode peer tutoring, dan mengkerucut menjadi bimbingan belajar mata pelajaran matematika yang belum dipahami peserta didik kelas 1, 2, dan 3.

2) Bimbingan Membaca, Menulis, dan Berhitung. Kegiatan ini yaitu kegiatan bimbingan bagi peserta 
didik kelas 1, 2, dan 3 yang belum menguasai kemampuan calistung.

\section{HASIL \& PEMBAHASAN}

\section{Hasil}

Rumah Pintar merupakan wadah bagi masyarakat, terutama peserta didik, karena mampu menjembatani peserta didik dengan fasilitas dan penyelenggaraan pembelajaran. (Rumah \& Tresno, n.d.) Rumah Pintar ini dibuat bertujuan untuk membantu peserta didik yang tidak memiliki fasilitas penunjang pembelajaran jarak jauh dan membantu peserta didik kelas rendah (Kelas 1, 2, dan 3) dalam rangka meningkatkan kemampuan membaca, menulis, dan berhitung.

Pelaksanaan kegiatan pengabdian ini berlangsung selama 38 hari dengan yang bertempat di TKQ PLUS An-Nur Kp. Maleber selama tiga hari seminggu (Selasa, Kamis, dan Sabtu) dan dua kali seminggu (Rabu dan Jum'at) di Madrasah Kp. Sudimampir. Sebagai pusat sumber program Rumah Pintar kami melaksanakan kegiatan edukatif lainnya, yang terdiri dari :

\section{Tabel 1. Kegiatan Rumah Pintar}

\begin{tabular}{lll}
\hline Program & Keterangan & Kegiatan \\
\hline Bimbingan & Mengajar kelas & - Pembukaan \\
Belajar & rendah (1, 2, & Pembelajaran \\
& dan 3). pada & (Membaca do'a \\
& pelajaran & sebelum belajar, \\
& matematika & menanyakan
\end{tabular}

kabar, dan ice breaking)

- Pembarian materi terlebih dahulu oleh pembimbing kepada siswa secara menyeluruh

- Penggunaan buku bacaan, buku tema, dan internet (Youtube, Google). Evaluasi peserta didik

- Motivasi diri

\begin{tabular}{|c|c|c|}
\hline $\begin{array}{l}\text { Bimbingan } \\
\text { Calistung }\end{array}$ & $\begin{array}{l}\text { Mengajar kelas } \\
\text { rendah (1, 2, } \\
\text { dan 3) yang } \\
\text { belum mahir } \\
\text { membaca, } \\
\text { menulis, dan } \\
\text { berhitung. }\end{array}$ & $\begin{array}{r}\text { - Mengajar Peserta } \\
\text { didik satu persatu }\end{array}$ \\
\hline $\begin{array}{l}\text { Kegiatan } \\
\text { membantu } \\
\text { Mengajar } \\
\text { di TKQ } \\
\text { PLUS AN- } \\
\text { Nur }\end{array}$ & $\begin{array}{l}\text { Kegiatan } \\
\text { menyesuaikan } \\
\text { dengan tema } \\
\text { pembelajaran. }\end{array}$ & $\begin{array}{l}\text { - Pembukaan } \\
\text { Pembelajaran } \\
\text { (Membaca do'a } \\
\text { sebelum belajar, } \\
\text { menanyakan } \\
\text { kabar, dan ice } \\
\text { breaking) } \\
\text { - Pembarian materi } \\
\text { terlebih dahulu } \\
\text { oleh pembimbing } \\
\text { kepada siswa } \\
\text { secara } \\
\text { menyeluruh } \\
\text { - Penggunaan buku } \\
\text { bacaan, buku } \\
\text { tema, dan internet } \\
\text { (Youtube, } \\
\text { Google). } \\
\text { - Evaluasi peserta } \\
\text { didik } \\
\text { - Motivasi diri } \\
\text { - Mempelajari } \\
\text { Protokol } \\
\text { Kesehatan }\end{array}$ \\
\hline $\begin{array}{l}\text { Mengajar } \\
\text { TPA }\end{array}$ & $\begin{array}{l}\text { Kegiatan } \\
\text { dibuka dengan } \\
\text { do'a, } \\
\text { dilanjutkan } \\
\text { dengan } \\
\text { menulis materi }\end{array}$ & \\
\hline
\end{tabular}


berdasarkan

jadwal mata

pelajaran,

kegiatan

mengaji iqro,

bacalah, dan

hafalan,

dilanjut

dengan

mengajarkan

siswa secara

individu

terkait soal

yang

dikerjakan,

kemudia

penutup

Berdasarkan tabel di atas, kegiatan

bimbingan belajar berfokus pada mata pelajaran matematika dan kemampuan calistung, dan membantu mengajar di lembaga pendidikan TKQ dan TPQ. Adapun kegiatan tersebut berlangsung dalam jangka waktu pendek secara berkala yaitu, selama bulan Juli hingga Agustus 2020.

\section{Pembahasan}

Rumah Pintar sebagai program yang didalamnya terdapat kegiatan bimbingan belajar ini dijadikan sarana bagi peserta didik untuk melakukan pembelajaran secara langsung dengan mematuhi protokol kesehatan.

Pandemi Covid-19 yang melanda Indonesia bahkan dunia ini mengharuskan pemerintah mengalihkan pembelajaran menjadi menggunakan metode pembelajaran jarak jauh.
Sehingga peserta didik harus mampu menyesuaikan diri dengan proses pembelajaran ini. Pada Bimbingan belajar dan bimbingan calistung di Rumah pintar ini, kegiatan atau program bertujuan untuk membantu peserta didik yang tidak memiliki fasilitas dalam melakukan pembelajaran jarak jauh, dan bagi peserta didik yang belum menguasai kemampuan calistung.

Rumah Pintar merupakan salah satu sarana untuk pendukung proses belajar mengajar peserta didik, sebagai tempat luar sekolah yang membimbing dan mengajar peserta didik yang tidak memiliki fasilitas teknologi untuk melakukan pembelajaran jarak jauh.

Pelaksanaan program Rumah Pintar ini mendapat dukungan dari pihak SDN Sukamahi 02 dan peserta didik, terlihat dari antusiasnya peserta didik yang tidak hanya berasal dari Kp. Sudimampir dan Kp. Maleber saja tetapi dari kampun-kampung sekirnya seperti Kampung Babakan, PT. Hidon, dan Kampung Sukabirus.

Adanya Rumah Pintar ini dapat dirasakan peserta didik kelas 1, 2, dan 3 SD berdasarkan kegiatan yang diikuti masing-masing peserta didik sebagai 
sarana penunjang pembelajaran mereka. Output yang dihasilkan oleh program Rumah Pintar, yaitu adanya pemahaman siswa mengenai pentingnya belajar meskipun di masa Adaptasi Kebiasaan Baru dengan tetap mematuhi anjuran protokol kesehatan dan bertambahnya pengetahuan peserta didik yang mengikuti kegiatan bimbingan belajar, terutama mata pelajaran pada matematika.

Berikut output lain dari program pengabdian ini :

1. Meningkatnya motivasi belajar siswa yang selama ini menurun selama pendidikan jarak Jauh (PJJ).

2. Adanya pemahaman peserta didik terhadap pelajaran matematika.

3. Meningkatnya kemampuan membaca, menulis, dan berhitung (CALISTUNG) peserta didik kelas 1 dan 3 SD.

Tabel 2 Output Program Rumah Pintar

\begin{tabular}{|c|c|}
\hline Kegiatan & Output \\
\hline Bimbingan & Menumbuhkan motivasi belajar di \\
\hline \multirow[t]{3}{*}{ Belajar } & Era New Normal. \\
\hline & $\begin{array}{l}\text { Penerapan metode pembelajaran } \\
\text { peer tutoring dan interaktif, yang } \\
\text { menumbuhkan belajar peserta didik }\end{array}$ \\
\hline & $\begin{array}{l}\text { terhadap mata pelajaran } \\
\text { matematika, mengetahui do'a } \\
\text { sebelum dan sesudah belajar yang } \\
\text { bisa terus diamalkan. }\end{array}$ \\
\hline Bimbingan & Meningkatkanya \\
\hline Calistung & $\begin{array}{l}\text { mambaca kata kalimat dan } \\
\text { mengenal alfabet, tumbuhnya } \\
\text { kesadaran peserta didik tentang } \\
\text { pentingnya belajar. }\end{array}$ \\
\hline
\end{tabular}

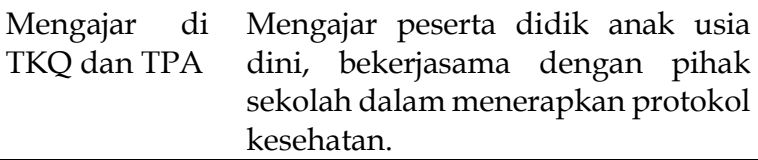
TKQ dan TPA dini, bekerjasama dengan pihak sekolah dalam menerapkan protokol kesehatan.

\section{SIMPULAN}

Dari pelaksanaan program Rumah Pintar di Kampung Maleber dan Kampung Sudimampir Desa Sukamahi, dapat disimpulkan kegiatan ini meningkatkan pemahaman dan pengetahuan peserta didik akan pentingnya belajar meskipun fasilitas pembelajaran jarak jauh kurang mencukupi, membuhkan semangat belajar peserta didik untuk menimba ilmu dan menguasai kemampuan calistung tentunya dengan mematuhi protokol kesehatan.

Kegiatan ini membuktikan bahwa bentuk kegiatan serupa dibutuhkan oleh masyarkat, terutama bagi anakanak di masa pandemic Covid-19. Oleh karena itu, di masa yang akan datang para akademisi diharapkan mampu untuk menyalurkan pengetahuan dan ilmunya pada masyarakat secara langsung maupun tidak langsung, baik melalui program pengabdian maupun melalui sistem pendidikan yang mendukung. 
UCAPAN TERIMA KASIH

Ucapkan terima kasih dan apresiasi disampaikan kepada aparat Desa Sukamahi yang telah memberikan izin pada kami untuk melaksanakan program. Ucapan terima kasih juga disampaikan kepada SDN Sukamahi 02, TKQ PLUS AN-Nur, dan seluruh warga Desa Sukamahi yang telah berkontribusi dalam pelaksanaan program bimbingan belajar Rumah Pintar.

\section{DAFTAR PUSTAKA}

Ardiyanti, S., Marlenywati, Rahayu, H.M. (2019). Upaya

Pengembangan Pendidikan Anak Melalui Kegiatan Rumah Pintar di Desa Sungai Mawang Kabupaten Sanggau. Jurnal SOLMA Vol 8 No.1, 5-13.

Armiatin, Septiwihartini, D., Gagaramusu, Y. (2015). Meningkatkan Hasil Belajar Siswa Pada Mata Pelajaran PKn Di Kelas V SDN No. 4 Pangalasiang Melalui Bimbingan Kerja Kelompok. Jurnal Kreatif Tadulako Online Vol 3 No 4, 200-214.

El Fiah, R., \& Purbaya, A. P. (2016). Penerapan Bimbingan Belajar dalam Meningkatkan Hasil Belajar Peserta Didik di SMP Negeri 12 Kota Bandar Lampung Tahun Pelajaran 2015/2016. KONSELI: Jurnal Bimbingan Dan Konseling (EJournal), 3(2), 161-174.

Huda, J. (20013). Meningkatkan Motivasi Belajar Siswa Melalui Optimalisasi Layanan Bimbingan Belajar Secara Kelompok Dan
Individu. Vidya Karya Jurnal Kependidikan Vol 28 No.1.

Kemenkes. (2020). Dokumen resmi. Pedoman Kesiapan Menghadapi COVID-19, 0-115.

Marsuki, Rokhyanto, Listiani, W. (2017). IbM Kelompok Bimbingan Belajar Di Kelurahan Bandungrejosari Dan Bakalankrajan Kecamatan Sukun Malang Jawa Timur. JPM PAMBUDI Vol 1 No 1, 74-81.

Meidyna, F. G. (2018). Kontribusi keikutsertaan bimbingan belajar dan motivasi belajar terhadap nilai akademik siswa kelas xii jurusan pemasaran di lbb epsilon gresik. Jurnal Pendidikan Tata Niaga Vol 7 No 3.

Nihayah. (2018). Pengaruh Bimbingan

Belajar Terhadap Kejenuhan

Dalam Belajar Pada Siswa Kelas Xi

Di SMAN I Gerung Kabupaten Lombok Barat. Jurnal Kajian Dan Penelitian Pendidikan Islam Vol 12 No 1 53-64.

Nurhayati. (2016). Meningkatkan Hasil Belajar Siswa Dengan Menggunakan Metode Bimbingan Mata Pelajaran IPA di Kelas III SD Inpres 1 Bainaa. Jurnal Kreatif Tadulako Online Vol 4 No. 10.

Pelaksanaan, P. (2014). Pengabdian masyarakat. 1-9.

Pengantar, K. (2011). Direktorat Pembelajaran Dan Kemahasiswaan.

Peraturan Pemerintah Nomor 17 Tahun 2010 tentang Pengelolaan dan Penyelenggaraan Pendidikan.

Peraturan Pemerintah Nomor 66 Tahun 2010 tentang Pengelolaan dan Penyelenggaraan Pendidikan.

Rumah, G., \& Tresno, P. (n.d.). Gambar 1. Gedung Rumah Pintar Tresno Asih. 138-155.

Satria, A., \& Hasanah, H. (2019). Desa 
Tangguh Covid-19. 2019, 107-122.

Surat Keputusan Bersama Menteri

Pendidikan dan Kebudayaan,

Menteri Kesehatan, Menteri

Agama, dan Menteri Dalam Negeri

Republik Indonesia Tahun 2020

tentang Penyelenggaraan

Pembelajaran Tahun Pembelajaran

2020/2021 di Masa Pandemi

Covid-19.

Surat Keputusan Mendiknas No.

107/U/2001 Tentang

Penyelenggaraan Pendidikan Jarak Jauh.

Syardiansah. (2019). Pengembangan

Kompetensi Mahasiswa ( Studi

Kasus Mahasiswa Universitas

Samudra KKN Tahun 2017 ). Jim

Upb, 7(Studi Kasus Mahasiswa

Universitas Samudra KKN Tahun 2017), 57-68.

Undang-undang No. 20 Tahun 2003

Tentang Sistem Pendidikan

Nasional. 